James K. Alifimoff MD, Barbara W. Brandom MD, David R. Cook MD

We studied the effect of halothane, enflurane and isoflurane on angiotensin converting enzyme (ACE) activity using $\left[{ }^{3} H\right]$-benzoyl-phenylalanyl-alanyl-proline (BPAP) as a substrate. lsolated rabbit lungs were perfused in a recirculating system in vitro with $B P A P$ in Krebs-Ringer solution. The rate of metabolism and per cent metabolism were determined before and after treatment for $30 \mathrm{mi}$ nutes with four MAC multiples of enflurane, halothane or isoflurane. The effects of the anaesthetics on ACE activity were determined by calculating per cent inhibition of metabolism of BPAP using data from the control and test period for each lung. The average metabolism of BPAP at 15 minutes during the control period was 76.5 per cent ( \pm 1.92 SEM). No anaesthetic significantly inhibited metabolism of BPAP. Likewise there was no effect on BPAP first order kinetics. Although potent inhalation anaesthetics may alter the renin-angiotensinaldosterone axis, they do not affect this crucial step.

\section{Key words}

ANAESTHETICS, VOLATILE: enflurane, halothane, isoflurane; BLOOD PRESSURE: angiotensin I, angiotensin II, angiotensin converting enzyme; LUNG: angiotensin converting enzyme.

From the Departments of Anaesthesiology, Children's Hospital of Pittsburgh and University of Pittsburgh School of Medicine, Pittsburgh, Pennsylvania.

Presented at the 1983 Annual Meeting of the American Society of Anesthesiologists.

Address correspondence to: Dr. Cook, 125 DeSoto Street, Pittsburgh, PA 14213.

\title{
Enflurane, halothane and isoflurane do not inhibit angiotensin converting enzyme activity
}

Plasma renin activity does not increase with halothane, enflurane, or fluroxene anaesthesia.' Blood pressure, however, significantly decreased when a competitive inhibitor of angiotensin II, saralasin, was administered to animals anaesthetized with halothane or enflurane but not with ketamine or fluroxene. ${ }^{1}$ Since inhibition of angiotension converting enzyme (ACE), a dicarboxypeptidase located on the endothelial surface of the pulmonary vasculature that catalyzes the formation of angiotensin II, might explain these findings Miller et al. examined the effects of these agents in vitro on isolated rabbit $\mathrm{ACE}$ and in vivo using blood pressure dose-response curves to angiotensin I and II. ${ }^{2}$ In the in vitro study they found that a substrate concentrations of $2.8 \times 10^{-5} \mathrm{M}$, halothane (two per cent) significantly inhibited ACE activity; at fourfold higher substrate concentrations no inhibition of ACE was observed. Although the direct effects of halothane on ACE were judged to be slight by Miller et al. ${ }^{2}$ we estimated (from these in vitro data) that ACE activity was inhibited about 50 per cent by halothane at each substrate concentration. This suggests a model of either competitive or noncompetitive inhibition.

There are several methodologic difficulties in determining ACE activity on the basis of bioassay that warrant reinvestigation of the effects of halothane on ACE. First, bioassay provides only indirect evidence of conversion. Second, a significant amount of the vasopressor activity obtained after passage of angiotensin I through lung is due to a compound which is neither angiotensin I nor angiotensin $11 .^{3}$ This material would obviously be accounted for as being angiotensin II if a bioassay were used. Third, while Miller's in vitro studies used two per cent halothane, the in vivo bioassay 


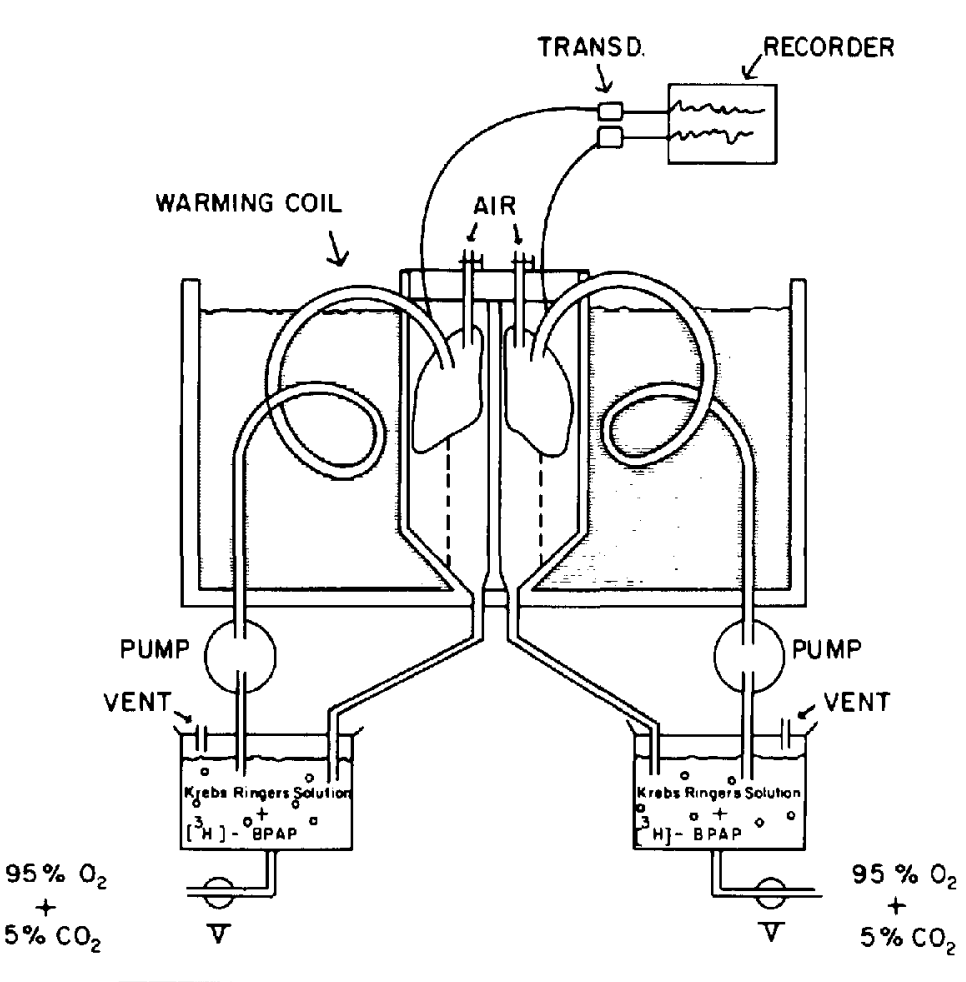

FIGURE 1 Schematic drawing illustrating perfusion apparatus for isolated perfused rabbit lung. $\hat{V}$, anesthetic specific calibrated vapourizer; transd., pressure transducer. Drawing adapted from: Naito $\mathrm{H}$ and Gillis GN: Effects of halothane and nitrous oxide on removal of norepinephrine from the pulmonary circulation. Anesthesiology 1973; 39: 565-80.

examined rats anaesthetized with 1.3 per cent halothane. ${ }^{2}$ Thus inhibition may have been obscured by decreasing the concentration of a potential inhibitor. Finally, several investigators have demonstrated that angiotensin II is 1.7 times greater in its pressor response than angiotensin $\mathrm{I}^{4.5}$ This was not observed in the control group of Miller et al. ${ }^{2}$

For these reasons, we used the synthetic $\mathrm{ACE}$ substrate $\left[{ }^{3} \mathrm{H}\right]$-benzoyl-phenylalanyl-alanyl-proline (BPAP) to re-examine the effects of halothane, enflurane and isoflurane on ACE in isolated perfused rabbit lung.

\section{Methods}

Experiments were performed using rabbit lung preparations perfused in a manner previously described. ${ }^{6,7}$ New Zealand white rabbits $(2.5$ to
$3.0 \mathrm{~kg}$ ) were intravenously anaesthetized with thiopentone $\left(25 \mathrm{mg} \cdot \mathrm{kg}^{-1}\right)$ and heparinized ( 1000 units! rabbit). Their hearts, lungs and tracheas were excised en bloc from the thorax. After isolation of the main pulmonary artery, the heart was cut from the preparation, connective tissue was excised, and the trachea and each pulmonary artery were cannulated; the pulmonary veins were opened to allow free drainage of effluent. The left and right lungs were statically inflated with 20 to $25 \mathrm{ml}$ of room air and were placed in a water-jacketed, humidified incubation chamber maintained at $37^{\circ} \mathrm{C}$. Pulmonary arterial pressure was continuously monitored using a pressure transducer. The lungs were perfused independently but concurrently in a closed system via each pulmonary artery at a constant flow rate of ten $\mathrm{ml}$ per minute with Krebs-Ringer bicarbonate-dextrose solution with the following com- 
position (mM): $\mathrm{NaCl}$ (118), $\mathrm{KCl}$ (4.63), $\mathrm{CaCl}_{2}$ (2.54), $\mathrm{KH}_{2} \mathrm{PO}_{4}(1.17) ; \mathrm{MgSO}_{4}(1.16), \mathrm{NaHCO}_{3}$ (25.0), and dextrose $(11.1)$ at $37^{\circ} \mathrm{C}$. The perfusate was saturated by bubbling with 95 per cent oxygen and 5 per cent carbon dioxide; the $\mathrm{pH}$ was maintained between 7.35 and 7.45 (Figure 1).

\section{Experimental procedures}

Each lung was perfused for ten minutes with oxygenated Krebs-Ringer solution to clear the lung of residual blood and thiopentone. After this washout period, the lungs were perfused in a recirculating system from a $100-\mathrm{ml}$ reservoir containing $0.2 \mathrm{nM}$ BPAP ((25 $\mathrm{mCi} / \mathrm{mMol})$ Ventrex Laboratories, Portland, MA) in Krebs-Ringer solution for 15 to 16.5 minutes. The reservoir was sampled at three-minute intervals for determination of parent compound and metabolite to determine control ACE activity. ${ }^{8-10}$

\section{Anaesthetic experiment}

Following determination of control ACE activity in this manner, residual radioactivity was washed from the lungs for five minutes with oxygenated Krebs-Ringer solution. The lungs were then perfused with a recirculating system for 30 minutes from a $100 \mathrm{ml}$ reservoir of Krebs-Ringer solution previously equilibrated with the anaesthetic gas being tested. The concentration of anaesthetic was maintained during this 30 minute period by delivering enflurane 6.7 per cent, halothane 3.0 per cent or isoflurane 5.1 per cent into the perfusion reservoir with an anaesthetic specific, calibrated vaporizer with a flow of three liters per minute of 95 per cent oxygen and 5 per cent carbon dioxide. We assumed the MAC of halothane to be 0.75 per cent, the MAC of enflurane to be 1.68 per cent, and the MAC of isoflurane to be 1.28 per cent; these are the MAC values for adults (human). The delivered concentrations correspond to four MAC of each anaesthetic.

After treatment of the lungs with anaesthetic for 30 minutes, determination of BPAP metabolism was repeated by perfusing the lungs in a recirculating system with Krebs-Ringer solution for 15 to 16.5 minutes with new 0.2 nM BPAP. The KrebsRinger solution had been previously equilibrated with the anaesthetic being tested; the concentration of anaesthetic gas was also kept constant during this period. The reservoir was again sampled at three minute intervals for determination of parent com- pound and metabolite. $\mathrm{pH}$ remained stable between 7.35 and 7.45 during this period. A minimum of six separate lungs were studied for each anaesthetic.

\section{Additional studies}

Additional lungs were perfused for 30 minutes with Krebs-Ringer solution to demonstrate the stability of the isolated lung preparation $(n=4)$ or were perfused with $1 \times 10^{-4} \mathrm{M}$ captopril $(n=4)$ to document that known inhibitors of ACE could inhibit BPAP metabolism in this system.

\section{Measurement of BPAP metabolism}

Aliquots from the reservoir $(1.0 \mathrm{ml})$ were acidified with $0.04 \mathrm{ml}$ of $2.5 \mathrm{~N} \mathrm{HCl}$ then mixed with $1.0 \mathrm{ml}$ of toluene to extract $\left[{ }^{3} \mathrm{H}\right]$-Benzoyl-Phenylalanine (BPhe), the hydrolysis product of BPAP. ${ }^{8}$ After centrifugation for 20 minutes at $3,000 \mathrm{rpm}$, the amount of tritium extracted into toluene was determined with liquid scintillation spectrometry by adding $0.5 \mathrm{ml}$ of the organic phase to $4.0 \mathrm{ml}$ of

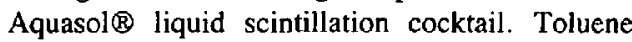
preferentially extracts the metabolite, BPhe, but also about five per cent of the parent BPAP. ${ }^{9}$ The amount of BPhe in the sample was corrected for the variable distribution of BPAP and BPhe in the acid organic phase using simultaneous equations with appropriately calculated partition coefficients. ${ }^{10}$ Radioactivity of a 0.5 -ml aliquot, obtained from the perfusion reservoir at the same times, was measured to determine total radioactivity. Disintegrations per minute (dpm) were calculated from appropriate quench curves. The concentration of parent compound $\left(\mathrm{nmol} \cdot \mathrm{ml}^{-1}\right)$ and metabolite $\left(\mathrm{nmol} \cdot \mathrm{ml}^{-1}\right.$ ) were calculated at each time period. Radioactivity (dpm) associated with the parent compound was the difference between the total disintegrations per minute and the disintegrations per minute of the metabolite. ${ }^{9,10}$

\section{Calculation of half-life and percentage of metabolism}

A plot of log concentrations of BPAP against time revealed a linear relationship which suggested that first-order kinetics were applicable over the period studied (Figure 2). The slope, $K_{10}$, of the plot of log concentration over time was calculated from a regression analysis; therefore $\mathrm{Ke}=\mathrm{K}_{10} / 2.303$. The half-life $(t 1 / 2, \mathrm{~min})$ was calculated from the relationship $t^{1} / 2=0.693 / \mathrm{Ke}$. 


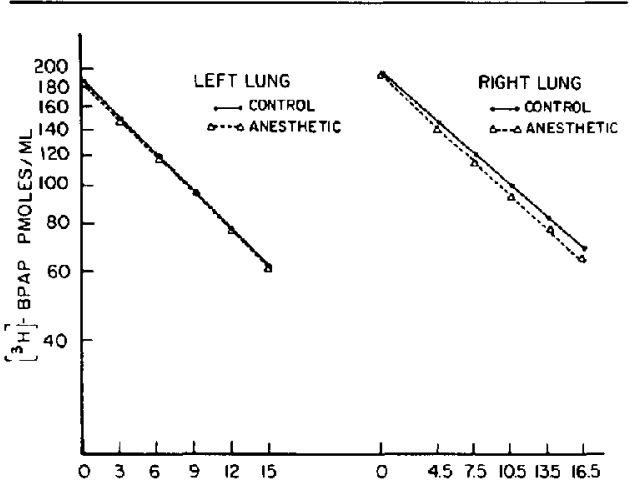

FIGURE 2 Semilogarithmic plot of concentration of $\left[{ }^{3} \mathrm{H}\right]$-BPAP in perfusion reservoir versus time (in minutes) for left and right lungs from a typical experiment. '- ' control ACE activity. $\triangle--\triangle A C E$ activity after treatment with three per cent halothane.

The per cent metabolism of BPAP was calculated at each time period using the relationship:

Per cent Metabolism $(\% \mathrm{M})=\left[\mathrm{C}_{0}-\mathrm{C}_{\mathrm{t}}\right] / \mathrm{C}_{\mathrm{o}} \times 100$

(where $\mathrm{C}_{0}=$ concentration of BPAP in reservoir at time 0 , and $C_{t}=$ concentration of BPAP in reservoir at time $t$ ).

In addition, the effects of Krebs-Ringer solution, captopril or the anaesthetics on BPAP metabolism were determined by calculating the per cent inhibition of BPAP metabolism using data from the control and test period of each lung at 15 minutes. Per cent inhibition of metabolism was determined from the formula:

Per cent inhibition $(\% \mathrm{I})=\left[\mathrm{M}_{\mathrm{c}}-\mathrm{M}_{\mathrm{t}}\right] \mathrm{M}_{\mathrm{c}} \times 100$

(where $\mathrm{M}_{\mathrm{c}}=$ per cent metabolism during the control period and $M_{\mathbf{l}}=$ per cent metabolism during the test period).

\section{Statistical analysis}

Statistical significance of differences in $t^{1 / 2}$ and per cent metabolism from control and treatment period was assessed with a Wilcoxon signed rank test. Comparisons of differences in $t / 2$ and per cent metabolism between Krebs-Ringer and anaesthetic treated lungs were made with a Wilcoxon sign rank test. Comparisons of per cent inhibition by different anaesthetics were made with a one-way analysis of variance. Significance was assumed at the $p<0.05$ level.

\section{Results}

The $t 1 / 2$ for the rate of BPAP metabolism during all contral periods was 7.28 minutes $( \pm 0.26 \mathrm{SEM}$ ) and the per cent metabolism of BPAP (at 15 minutes) was 76.7 per cent ( \pm 1.20 SEM) (Tables I and II).

Perfusion of lungs with Krebs-Ringer's solution for 30 minutes did not cause a significant increase in the $t / 2$ for BPAP metabolism or decrease the per cent metabolism of BPAP; hence, time per se caused no inhibition of BPAP metabolism ( $p>$ 0.50 ) (Table I). Treatment with captopril significantly increase $t / 2$ of BPAP metabolism and decreased the per cent metabolism of BPAP; there was almost complete inhibition of BPAP metabolism (Table I) $(p<0.05)$. There was no statistically significant difference in $t / 2$ or per cent metabolism of BPAP when anaesthetic treated lungs were compared to control (Table II) or to 30 minute Krebs-Ringer treated lungs ( $\mathrm{p}>0.50$ ).

During the control and treatment determination of ACE activity there was no increase in perfusion pressure. Likewise, there was no significant difference in wieght gain.

\section{Discussion}

In prior studies ${ }^{6}$ we found that potent anaesthetics inhibit the active uptake of 5-hydroxytryptamine by the lung. Likewise, Naito and Gillis ${ }^{7}$ noted inhibition of norepinephrine removal by the lung by both halothane and nitrous oxide. Most likely a common mechanism is involved (e.g., inhibition of aerobic metabolism, inhibition of sodium-potassium ATPase, or alteration in membrane permeability). In contrast, neither enflurane, halothane, nor isoflurane at four MAC significantly altered ACE activity in isolated perfused rabbit lung. Inhibition of $\mathrm{ACE}$ by lower multiples of MAC is thus unlikely.

Miller et $a l^{2}{ }^{2}$ demonstrated approximately 50 per cent inhibition of ACE by two per cent halothane using enzyme isolated from rabbit lung. However, when the effect of halothane on ACE was examined in vivo using blood pressure dose-response curves to angiotensin I and II, no significant effect was observed. While this latter result is in agreement with our study, the present work was warranted for 
TABLE I Effect of Krebs Ringer solution and captopril on metabolism of $\left[{ }^{3} \mathrm{H}\right]$-benzoyl-phenylalanyl-alanyl-proline in isolated rabbit lungs (mean \pm SEM)

\begin{tabular}{|c|c|c|c|c|c|}
\hline & \multicolumn{2}{|l|}{$t 1 / 2(\min )$} & \multicolumn{2}{|c|}{ Per cent metabolism at 15 minutes } & \multirow{2}{*}{$\begin{array}{l}\text { Per cent } \\
\text { inhibition }\end{array}$} \\
\hline & Control & Treated & Control & Treated & \\
\hline $\begin{array}{l}\text { Krebs Ringer } \\
(n=4)\end{array}$ & $7.36 \pm 0.35$ & $7.84 \pm 0.29$ & $76.3 \pm 1.48$ & 73.71 .31 & $3.40 \pm 1.79$ \\
\hline $\begin{array}{l}\text { Captopril }\left(1 \times 10^{-4} \mathrm{M}\right) \\
(\mathrm{n}=4)\end{array}$ & $7.10 \pm 0.32$ & $153 \pm 73.1 * \dagger$ & $77.8 \pm 1.35$ & $11.3 \pm 2.45 * \dagger$ & $85.6 \pm 3.09 *$ \\
\hline
\end{tabular}

${ }^{*} p<0.05$ as compared to control.

$t p<0.05$ as compared to Krebs Ringer.

TABLE II Effect of anesthetics on metabolism of $\left[{ }^{3} \mathrm{H}\right]$ benzoyl-phenylalanyl-alanyl-proline in isolated rabbit lungs $($ mean $=$ SEM)

\begin{tabular}{|c|c|c|c|c|c|}
\hline \multirow[b]{2}{*}{ Anaesthetic } & \multicolumn{2}{|l|}{$t^{1 / 2}(\min )$} & \multicolumn{2}{|c|}{ Per cent removal at 15 minutes } & \multirow[b]{2}{*}{$\begin{array}{l}\text { Per cent } \\
\text { inhibition }\end{array}$} \\
\hline & Control & $\begin{array}{l}\text { Treated } \\
\text { (anaesthetic) }\end{array}$ & Control & $\begin{array}{l}\text { Treated } \\
\text { (anaesthetic) }\end{array}$ & \\
\hline $\begin{array}{l}\text { Enflurane }(6.7 \%) \\
\mathrm{N}=6\end{array}$ & $7.23 \pm 0.48$ & $7.24 \pm 0.40$ & $76.5 \pm 2.33$ & $76.3 \pm 1.87$ & $0.02 \pm 2.24$ \\
\hline $\begin{array}{l}\text { Halothane }(3 \%) \\
\mathrm{N}=6\end{array}$ & $7.66 \pm 0.82$ & $8.28 \pm 0.40$ & $75.3 \pm 3.62$ & $71.7 \pm 1.71$ & $4.15 \pm 3.34$ \\
\hline $\begin{array}{l}\text { Isoflurane }(5.1 \%) \\
\mathrm{N}=6\end{array}$ & $7.05 \pm 0.91$ & $7.73 \pm 1.08$ & $77.7 \pm 4.33$ & $74.8 \pm 5.01$ & $3.90 \pm 3.74$ \\
\hline
\end{tabular}

several reasons. First, while Miller's in vitro data suggested either competitive or noncompetitive inhibition by two per cent halothane, the in vivo studies examined rats anaesthetized with 1.3 per cent halothane. This is a 35 per cent decrease in the concentration of a potential inhibitor. Furthermore, the halothane was "delivered via a small nose cone by a Drager vaporizer at approximately $1.3 \mathrm{vol}$ per cent." 2 Unless a tight mask fit were provided, the alveolar concentration of halothane may have been even less than 1.3 per cent. Neither end-tidal nor vaporizer-delivered anaesthetic concentrations were measured in that study. Since the rate of a reaction is strictly dependent on the relative concentrations of substrate and inhibitor, ${ }^{11}$ inhibition may have been obscured by decreasing inhibitor concentration. Second, the use of blood pressure doseresponse curves must be viewed with caution; response by bioassay provides only indirect evidence of conversion of angiotensin I to angiotensin II. Moreover, Ryan et al. ${ }^{3}$ demonstrated that when angiotensin $I$ is perfused through rat lungs as much as half of the pressor activity of the venous effuent is due to a substance other than angiotensin II. They state "whether the second substance is an endogenous compound in lung or a lower homologue of angiotensin 1 is not known." "This substance would obviously be accounted for as angiotensin II if only blood pressure dose-response curves were used. Finally, Miller used equal doses of angiotensin I and II on a weight basis. However, angiotensin II produces 1.7 times greater pressor response as compared to angiotensin I when equal weights are compared ${ }^{4,5}$ One would have therefore expected a proportionally greater pressor response to angiotensin II in this assay, which was not observed. ${ }^{2}$

The importance of ACE in blood pressure homeostasis has led many investigators to employ angiotensin $I$ as a substrate in various biological, colorimetric or radioimmunologic assays of $\mathrm{ACE}$ activity. ${ }^{2,12-14}$ Such assays, however, suffer from interference by other endogenous endo- and aminopeptidases, ${ }^{15}$ which degrade both substrates and products. Thus separation of products is necessary to distinguish between products of ACE and other enzymes. The advantages of using BPAP to study $A C E$ activity is that it is a specific substrate for $A C E$ which is resistant to hydrolysis by other pepidases. ${ }^{8}$ 
While BPAP was shown by Ryan et al. to be a specific substrate for both blood and pulmonary ACE, ${ }^{8}$ Catravas et al. ${ }^{9}$ demonstrated that the contribution of blood ACE to BPAP metabolism is minimal (two per cent). Residual blood was washed from the pulmonary vasculature in our studies, so that only the effects of inhalation agents on pulmonary $A C E$ are reflected. The fact that BPAP mnetabolism was not inhibited by 30 minutes of perfusion with Krebs-Ringers solution alone demonstrates that there was no deterioration of ACE activity during the study period.

Our data, which demonstrate almost complete inhibition of ACE activity by captopril, confirm that of others obtained both in vitro and in vivo; captopril is a competitive inhibitor of angiotensin I metabolism both in vitro and in vivo. Ryan et al. have shown that BPAP metabolism is completely inhibited by captopril at $10^{-6} \mathrm{M}$ concentrations in cultured endothelial cells. ${ }^{8}$ Captopril at doses of $6 \mathrm{nMol} \cdot \mathrm{Kg}^{-1}$ to $28 \mathrm{nMol} \cdot \mathrm{kg}^{-1}$ inhibits BPAP metabolism in an in vivo rabbit lung preparation in a dose dependent manner. ${ }^{9}$

Ryan et al. calculated the $\mathrm{Km}$ of BPAP to be $5 \times 10^{-6} \mathrm{M}^{3}$ Since BPAP in our studies was $0.2 \mathrm{nM}$ or 0.04 per cent of the $\mathrm{Km}$, BPAP metabolism showed first order kinetics as expected.

With respect to substrate concentrations, our data can be compared to those of Szidon ${ }^{16}$ who determined metabolism of angiotensin I by dog lung in vivo and Catravas ${ }^{9}$ who determined BPAP metabalism by dog and rabbit lung in vivo. Both of these investigators employed substrate concentrations well below the reported $\mathrm{Km}$. Under these conditions, Szidon ${ }^{16}$ reported $72 \pm 4$ per cent metabolism of angiotensin I, while Catravas ${ }^{9}$ showed $78 \pm 3$ per cent conversion of BPAP by dog lung and $70 \pm 2$ per cent by rabbit lung. We used a recirculation system and thus per cent metabolism is not necessarily comparable to these investigators who employed a single pass model. However, in preliminary studies we showed $76 \pm 3$ per cent metabolism of BPAP during a single pass through pulmonary circulation of the rabbit at similar substrate concentrations.

In summary we have shown that the potent inhalation agents do not alter the activity of ACE activity in isolated rabbit lung. This model allows examination of the conversion of angiotensin $I$ to angiotensin II without influence of other parts of the renin-angiotensin system.

\section{References}

1 Miller ED Jr, Longnecker DE, Peach MJ. The regulatory function of the renin angiotensin system during general anesthesia. Anesthesiology 1978; 48: 399-403.

2 Miller ED Jr, Gianfagna W, Ackerly JA, Peach MJ. Converting-enzyme activity and pressor responses to angiotensin I and II in the rat awake and during anaesthesia. Anesthesiology 1979; 50: 88-92.

3 Ryan $J W$, Stewart $J M$, Leary WP, Leringham $J G$. Metabolism of angiotensin I in the pulmonary circulation. Biochem J 1970; 120: 221-3.

4 Sealey $J E$, Gerten-Banes J, Laragh JH. The renin system: variations in man measured by radioimmune assay or bioassay. Kidney Int 1972; 1: 240-53.

5 Keeton TK, Campbell WB. The pharmacologic alteration of renin release. Pharm Rev 1981; 31: 81227.

6 Cook DR, Brandom BW. Enflurane, halothane, and isoflurane inhibit removal of S-hydroxytryptaminc from the pulmonary circulation. Anesth Analg 1982; 61: 671-5.

7 Naito $H$, Gillis $C N$. Effects of halothane and nitrous oxide on removal of norepinephrine from the pulmonary circulation. Anesthesiology 1973; 39: 565-80.

8 Ryan JW, Chung A, Martin LC, Ryan US. New substances for the radioassay of angiotensin converting enzyme of endothelial cells in cultures. Tissue and Cell 1978; 10: 555-62.

9 Catravas $J D$, Gillis $C N$. Metabolism of $\left[{ }^{3} \mathrm{H}\right]$-benzoyl-phenylalanyl-alanyl-proline by pulmonary angiotensin converting enzyme in vivo: effects of bradykinin, SQ14225 or acute hypoxia. J Pharmacol Exp Ther 1981; 217: 263-70.

10 Dobuler KJ, Catravas JD, Gillis CN. Early detection of oxygen-induced lung injury in conscious rabbits. Reduced in vivo activity of angiotensin converting enzyme and removal of 5-hydroxytryptamine. Am Rev Respir Dis 1982; 126: 534-8.

11 White A, Hanider P, Smith E. Principles of Biochemistry, 5th edition. New York: McGraw Hill, 1973; p. 223-47.

12 Helmer OM. Differentiation between two forms of angiotensin by means of spirally cut strips of rabbit aorta. Am J Physiol 1957; 188: 571-7. 
13 Dorer FE, Skeggs LT, Kahn JR, Lentz KE, Levine $M$. Angiotensin converting enzyme: method of assay and partial purification. 170; 33: 102-13.

14 Boyd GW, Landon J, Peart WS. Radioimmune assay for determining plasma levels of angiotensin II in man. Lancet 1968; 2: 1002-5.

15 Page IH, Bumpus FM (Eds). Angiotensin, Handbook of Experimental Pharmacology. New York: Springer Verlag, 1972, p. 37.

16 Szidon $P$, Bairey $N$, Oparil S. Effect of acute hypoxia on the pulmonary conversion of angiotensin I to angiotensin II in dogs. Circ Res 1980; 46: 221-5.

\section{Résumé}

On a étudiè l'effet de l'halothane, l'enflurane et l'isofurane sur l'activité de l'enzyme responsable de la conversion de l'angiotensine (ACE) utilisant le $\left.{ }^{3} \mathrm{H}\right]$-benzoyl-phenylalanyl-alanyl-proline (BPAP) comme substrat. Des poumans de lapins isolés ont été perfusés dans un système permettant une recirculation in-vitro avec le BPAP dans une solution de KrebsRinger. Le taux et le pourcentage du métabolisme ont été déterminés avant et après traitement pour 30 minutes avec des concentrations attégnant quatre fois le MAC d'enflurane, d'halothane ou d'isofurane. Les effets des anesthésiques sur l'activité du ACE ont été déterminés en calculant le pourcentage d'inhibition du métabolisme du BPAP utilisant les données de contrôle ainsi que les données du test pour chaque poumon. Le métabolisme moyen du BPAP à 15 minutes pendant la période de controle a été de 76.5 pour cent ( \pm 1.92 SEM). Aucun des anesthésiques a inhibé d'une façon significative le mérabolisme du BPAP. Aussi il n'y avait aucun effet sur la cinétique du premier ordre du BPAP. Même si les agents anesthésiques d'inhalation puissants peuvent altérer l'axe de la rénine-angiotensine-aldostérone, ils $n^{\prime}$ affectent pas cette étape cruciale. 